\title{
Serum gonadotrophins in Down's syndrome
}

\author{
W A CAMPBell, JUdith LOWTHER, IRENE MCKENZIE, AND W H PRICE \\ From the MRC Clinical and Population Cytogenetics Unit, and the University Department of Medicine, \\ Western General Hospital, Crewe Road, Edinburgh EH4 2 XU
}

SUMMARY Serum levels of follicle stimulating hormone (FSH) and luteinising hormone (LH) in institutionalised male patients with Down's syndrome (DS) have been found to be significantly higher than in age matched controls from the same institution. This difference is found in patients both under and over 30 years of age with respect to FSH levels, but the increase in LH levels is confined to patients with DS over 30 .

Although fertility among women with Down's syndrome is well documented, there has been no recorded case of paternity among males with this condition. Benda in $1960^{1}$ postulated that pituitary deficiency was a common feature of Down's syndrome and treatment with pituitary extract was used in some centres, although with little objective success. More recently, with the advent of readily available radioimmunoassay, studies of serum gonadotrophin levels in small numbers of patients with Down's syndrome have given conflicting results.

As part of a larger investigation of the reproductive endocrinology of males with DS, we have examined serum gonadotrophin levels and report the results in this paper.

\section{Patients and methods}

Seventeen male patients with DS, aged between 15 and 58 years, from a local hospital were chosen for the study and were matched for age and drug therapy with 17 male patients of known normal karyotype from the same hospital. The average age of the patients with DS was $30 \cdot 7$ years and of the controls 31.6 years. For DS patients and controls under 30 years of age, the mean age was $21 \cdot 1$ and 23.1 years, respectively. For those over 30 , the mean age was $39 \cdot 2$ years for the DS patients and 43. 7 years for the controls. All the patients agreed to a brief examination and single venepuncture.

All the patients with DS had a $47, \mathrm{XY},+21$ karyotype with the exception of one who also had a pericentric inversion of the $\mathrm{Y}$ chromosome.

The genitalia were examined with the patient standing and an assessment was made of pubic hair

Received for publication 27 April 1981 growth, penile development, and testicular consistency and size. A blood sample was taken and the serum separated and frozen for subsequent analysis.

FSH and LH were each measured using an $I^{125}$ competitive binding radioimmunoassay (Radiochemical Centre, Amersham). As the results did not appear to conform to a normal distribution, Wilcoxon's Rank Sum test was used in the assessment of significance.

\section{Results}

There was considerable variation in the development of pubic hair in the DS patients but it was generally sparser than in the controls. In almost all DS patients the testes were significantly smaller and softer than in the controls, this effect being most pronounced in the older patients. Penile development was normal. Genital and gonadal maturation in the controls was normal apart from one patient with hypospadias and one with an absent testis.

The results of the gonadotrophin assays are summarised in table 1. The patients with DS had significantly higher serum levels of FSH and LH than the controls. When the groups are divided into patients under and over 30 years of age (table 2), FSH levels of the DS patients were significantly higher in both age groups. LH levels, on the other

TABLE 1 Median FSH and LH levels $(\mathrm{mIU} / \mathrm{ml})$ and range in 17 patients with Down's syndrome and 17 controls

\begin{tabular}{|c|c|c|c|}
\hline \multicolumn{2}{|l|}{$F S H$} & \multicolumn{2}{|l|}{$L H$} \\
\hline $\begin{array}{l}\text { Down's } \\
\text { syndrome }\end{array}$ & Controls & $\begin{array}{l}\text { Down's } \\
\text { syndrome }\end{array}$ & Controls \\
\hline $\begin{array}{ll}22 \cdot 5 & \\
(6-89) & \\
& p<\end{array}$ & $\begin{array}{l}8 \cdot 5 \\
(2 \cdot 7-37 \cdot 5)\end{array}$ & $\begin{array}{l}21 \cdot 8 \\
(7 \cdot 8-100) \\
0.05\end{array}$ & $\begin{array}{l}12 \cdot 5 \\
(3 \cdot 9-26 \cdot 5) \\
>0 \cdot 01\end{array}$ \\
\hline
\end{tabular}


TABLE 2 Median FSH and LH levels $(\mathrm{mIU} / \mathrm{ml})$ and range in patients with Down's syndrome and controls under and over 30 years of age

\begin{tabular}{|c|c|c|c|}
\hline \multicolumn{2}{|l|}{$F S H$} & \multicolumn{2}{|l|}{$L H$} \\
\hline $\begin{array}{l}\text { DS } \\
\text { under } 30 y r \\
(n=8)\end{array}$ & $\begin{array}{l}\text { Controls } \\
\text { under } 30 y r \\
(n=8)\end{array}$ & $\begin{array}{l}D S \\
\text { under } 30 y r\end{array}$ & $\begin{array}{l}\text { Controls } \\
\text { under } 30 \mathrm{yr}\end{array}$ \\
\hline $\begin{array}{l}19 \cdot 8 \\
(6-56)\end{array}$ & $\begin{array}{l}7 \cdot 1 \\
(2 \cdot 7-21 \cdot 5)\end{array}$ & $\begin{array}{l}16 \cdot 2 \\
(7 \cdot 8-30)\end{array}$ & $\begin{array}{l}9 \cdot 0 \\
(3 \cdot 9-20)\end{array}$ \\
\hline $\begin{array}{l}D S \\
\text { over } 30 \text { yr } \\
(n=9)\end{array}$ & $\begin{array}{l}\text { Controls } \\
\text { over } 30 \text { yr } \\
(n=9)\end{array}$ & $\begin{array}{l}D S \\
\text { over } 30 y r\end{array}$ & $\begin{array}{l}\text { Controls } \\
\text { over } 30 \text { yr }\end{array}$ \\
\hline $\begin{array}{l}30 \\
(10 \cdot 8-113) \\
\quad p=\end{array}$ & $05^{11}(3 \cdot 4-37 \cdot 5)$ & $\begin{array}{l}32 \cdot 8 \\
(12 \cdot 5-100) \\
\quad p=0\end{array}$ & $\begin{array}{l}19 \cdot 8 \\
(5 \cdot 5-32)\end{array}$ \\
\hline
\end{tabular}

hand, were significantly increased only in the older patients with DS. In both groups, gonadotrophin levels tended to rise with age.

\section{Discussion}

Patients with DS are characteristically said to show some degree of sexual infantilism. ${ }^{1}$ The striking clinical finding in our series was the diminished testicular size at all ages. In the older patients the reduction in size was comparable to that seen in patients with Klinefelter's syndrome. We did not examine semen samples in our survey, but Stearns et $a l^{2}$ found oligospermia or azoospermia in the majority of patients with DS whom they studied, and Kjessler and de la Chappelle ${ }^{3}$ concluded that sterility in trisomy 21 may result from post-meiotic maturation failure.

That testicular failure in DS is primary in origin is supported by the high levels of FSH and LH found in our sample. Previous studies of males with DS have shown varying levels of gonadotrophins. Horan et $a l^{4}$ found raised FSH and LH levels in six males below the age of 30 , but Salvadorini et $a l^{5}$ found normal $\mathrm{LH}$ values in five.

It would seem from our results that the reported liability to premature functional failure in the thyroid and adrenal glands of patients with $\mathrm{DS}^{6}$ 7 occurs also in the testes, and further study of testicular function in patients with this condition is proposed. It is clear that, in contrast with earlier views, the pituitary gland in DS is capable of responding appropriately to feed-back from the testes.

We wish to thank Drs C B Whittaker and C T Preshaw and staff of Lynebank Hospital for their help and co-operation in making patients available, and $\operatorname{Dr} M$ Newton for clinical assistance. We are grateful to Mrs S Lochrie for typing the manuscript.

\section{References}

1 Benda CE. The child with mongolism. New York, London: Grune and Stratton, 1960.

2 Stearns PE, Droulard KE, Sahhar FH. Studies bearing on fertility of male and female mongoloids. Am J Ment Defic $1961 ; 65: 37-41$.

3 Kjessler B, de la Chapelle A. Meiosis and spermatogenesis in two post-pubertal males with Down's syndrome: 47,XY,G + . Clin Genet 1971;2:50-7.

4 Horan RF, Beitins IZ, Bode HH. LHRH testing in men with Down's syndrome. Acta Endocrinol 1978;88:594 600.

5 Salvadorini F, Saba P, Galeone F, et al. Indagini sulla dinamica dell' attività gonadotropa preipofisaria nella sindrome di Langdon-Down. Acta Neurol (Napoli) $1975 ; 30: 78-83$.

6 Murdoch JC, Gray CA, McLarty DG, Ratcliffe JG. Pituitary function in Down's syndrome. J Ment Defic Res $1978 ; 22: 273-5$.

7 Murdoch JC, Giles CA, Grant JK, Ratcliffe JG. Hypothalamopituitary-adrenocortical function in adults with Down's syndrome. J Ment Defic Res 1979;23:157-62.

Requests for reprints to Dr W A Campbell, MRC Clinical and Population Cytogenetics Unit, Western General Hospital, Crewe Road, Edinburgh EH4 2XU. 